\title{
Spiritual Leadership Management in Strengthening the Character of Students in Integrated Islamic Primary Schools
}

\author{
Nasir Usman*, Murniati A.R. \\ Educational Administration Postgraduate \\ Syiah Kuala University \\ Banda Aceh, Indonesia \\ *nasir@unsyiah.ac.id, nasir.fkip@gmail.com
}

\author{
Ulfah Irani Z. \\ STMIK \\ Banda Aceh, Indonesia
}

\begin{abstract}
This research aims at describing the sources, programs, and strategies of spiritual leadership management in strengthening the character of students in integrated Islamic primary schools. This research is a qualitative descriptive study. The instruments used are observation, interview, and documentation. Through this paper, we describe the sources that build student character values, the principal's spiritual leadership programs in strengthening the character of students, and the spiritual leadership strategies of principals. The results show that the sources that build student character values are from religion, nation, education, culture and norms. The principal's spiritual leadership program is integrated into curricular and extracullicular activities, habitution, and behaviour models; and the spiritual leadership strategy is carried out through exemplary, vision, mission and school goals, school distinctiveness icons, simulation and character building workshop, school activities and programs, and school management structure in charge of school culture and character.
\end{abstract}

Keywords-educational management, character education, integrated Islamic primary school, spiritual leadership

\section{INTRODUCTION}

In recent years, ethical problems, globalization, and acceleration of technology become prominent issues for the 21st century organization [1]. Modern management models seem unable to balance the turmoil and changes that occur in the organization. Many organization members seem to lose the value and endurance in facing the pressures and problems in the organization and life [2]. Therefore, we need an organizational management model that prioritizes moral values and goodness and focuses on organizational development [3]. One of these models is spiritual leadership management.

The spritual leadership management is believed to be able to offer a balance between employee resilience and organizational progress. The spiritual leadership management offers ethical leadership, employee well-being, sustainability, development of motivation social responsibility, and organizational commitment [4-6].
This research tries to apply the success of spiritual leadership management in educational sector. One of the inoptimal factors of implementation of character education in schools in Indonesia, Aceh in particular, is caused by the leadership crisis due to the decline in human values caused by ethical malaise and ethical crisis. Current leadership models in educational organization still view that the essence of leadership is only limited to a mandate from humans without appreciating that the position it gets is a mandate from humans and God [7]. So it is not surprising that school residents are encouraged to be materialistic and selfish, leaving an altruistic appeal that emphasizes exemplary, humanitarian and selfless values [6]. It is different from the spiritual leadership management, which is able to place the principal as a role model in inspiring inner life and job enrichment [8] for the environment. The spiritual leader is also a proactive who can change the way others "see"and "act" and influence others attitude and action with the objectives and has capacity to build trust and compassion [9]. So that, it is able to succeed in implementation of educational character building.

Furthermore, a principal also has authority which is marked by the presence of hierarchical dynamic between leader's control, power, subordinates' obediences, display control and authority by setting rules, determining responsibility, and issuing reward and punishment [7]. Therefore, it can facilitate planning and integration of character education in every policy and regulation that is made [10].

Besides that, spiritual leadership is able to bring sustainability in primary school since it is: (1) increasing joy, peace, and happiness of the environment; (2) using spiritual consciousness to see situations and problems from a holistic perspective; (3) engaging in moral and ethical behavior to make the right decision; (4) being inspired by vision and values; and (5) increasing love and trust for others [11].

This study is different from previous studies because this study tries to adopt an Islamic spiritual leadership management pattern which is then associated with strengthening the 
character of students. The significant role of Islamic based leadership could play in improving cross-cultural understanding, enhancing world quality and organizational effectiveness, it is related to altruistic love based on Al Qur'an and Sunnah [12].

This is in line with the concept of spiritual leadership management put forward by Fry that this model can create a vision where leader and followers feel a sense of calling so that their life have meaning coupled with hope/faith and establishing a social/organizational culture based on altruistic love includes trust/loyalty, forgiveness/acceptance, gratitude, integrity, honesty, courage, humility, kindness, compassion, patience/meekness, and endurance [5,13-17]. So, the ultimate effects of spiritual leadership are motivating and inspiring organization members through a transcendent vision and culture based on alturistic love $[2,13,15,18]$.

This study focuses on describing the sources that build student character values, the principal's spiritual leadership program in strengthening the character of students, and the spiritual leadership strategies of school principals in Aceh Province.

\section{A. Related Work}

1) Spiritual leadership management in education: Spiritual leadership theory is an emerging paradigm for organizational development and transformation that potentially guiding the evolution of positive organizations where human well-being and organizational level performance can be optimized [13]. In this study, what is meant by spiritual leadership management refers to the management of school principals and top management that prioritize spiritual values in every leadership policy, strategies and programs. Spiritual leadership management in education is the development of organizational learning through maximizing the inner motivation of students and employees in achieving organizational transformation [19].

Spiritual leadership is guided by the fundamental needs of both leaders and followers for spiritual well-being through (1) calling; the sense that one's life has meaning, purpose, and makes a difference, and (2) membership, or a sense that one is understood, appreciated, and accepted unconditionally $[2,14,16,17,20-22]$

The essential function of implementing spiritual leadership in organizations involves intrinsic motivation and inspiring workers through a shared vision and organizational culture based on altruism. Spiritual leadership has a positive impact on an organization as stated by Fry: (1) Organizational commitment; people with a sense of calling and membership will become attached, loyal to, and want to stay in organizations that satify these spritual needs; (2) productivity unit; people who experience calling and membership will be motivated to foster work unit continuous improvement and productivity to help the organization succeed; and (3) life satisfaction; people with a sense of calling and membership will feel more fulfilled by having a sense of purpose and belonging and therefore will perceive their lives as richer and of higher quality [15].

There are some guidelines for implementing spiritual leadership in school: (1) the organization must have a clear vision that they want $t$ be in present and future, (2) organization must have a culture that embody the idea of altruistic love, (3) organization must choose a leader with the ability to take backseat to being in charge and build a team of people who collectively share leadership responsibility [4].

The purpose of this spiritual leadership is to optimize strategy, empowerment of individuals and teams in establishing a consensus concerning toward organizational vision, values, behavior, inspiring employees' inner motivation, and causing employees to recognize the meaning of their work, and the call of mission, able to make changes, and feel understood and appreciated by their existence and work [23].

Based on the research conducted by Rezarch, she stated that spiritual leadership can serve as a model of effective leadership in independent schools since the independent schools are rigorous, competitive, with highly motivated constituencies, namely parents, students, and teachers, the principal and the teachers also have deepen capacity for connected to students, and resist the powerful draw of disconnected life [24,25].

Shaping the future of schools requires the vision of a leader who can encourage change [26]. A spiritual leader is able to inspire and motivate school members to raise the goals. The spiritual leadership can be a tool for students' inner development through activities conducted include conducting spiritual work in the form of a retreat, reflection, community building, volunteerism, creative endeavors, leadership development, teaching, learning, and writing [19].

2) Character development through spiritual leadership: Building students' characters cannot be raised instantly, it needs long time processes and done continuously, it should be started from basic education [8]. Character education is a disipline devoted to optimizing good characters, ethical behavior of students through action plans delegated to schools as providers of formal education $[10,25]$

Schools as formal educational institutions are responsible for strengthening the character of students through education and continuous guidance through learning interactions and other school activities. Strengthening the function of integrated Islamic schools as educational institutions and fostering students' character [25], in practice, relies on planned behavior theory based on three factors, namely: (1) attitude toward the behavior, (2) social norms regarding the behavior, (3) beliefs about one's control over the behavior [27].

By implementing spiritual leadership management, integrated Islamic schools can create an environment that supports the application of good character for students. The principal in this case acts as an exemplary and controller of the 
success of character education programs and activities in schools.

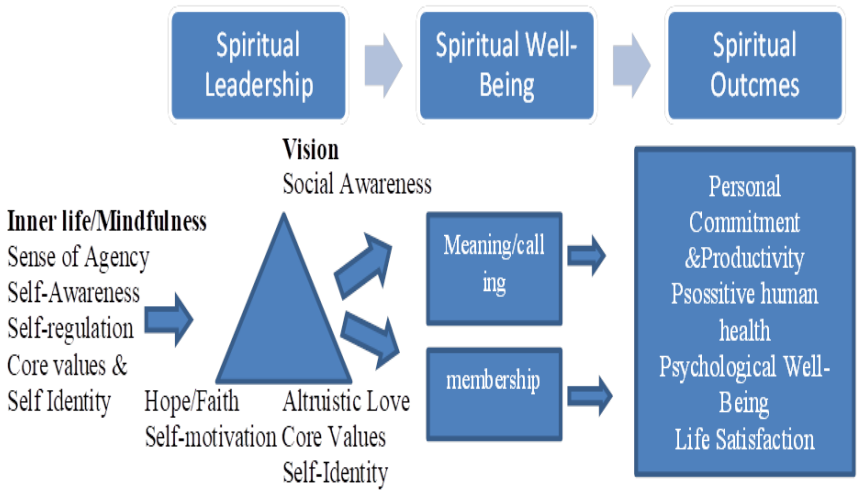

Fig. 1. A model of character development through spiritual leadership [21].

The model above shows in Figure 1 that the integration of the leader's core values and beliefs into the self-identity is at the heart of character development [21] for students at school. Character education is a mission that is embedded in the everyday life in school [23].

\section{THEORETICAL BACKGROUND}

In recent years, character education has emerged [28-30], likewise in Indonesia. Reffering to Article 3 the Indonesian Law Number 20 the Year of 2003, it states that the aim of educational goal is to achieve a holistic balance of human growth. Education should cover the development of all aspects of students' nature, such as: spiritual, intellectual, emotional, and physical aspects both individually and collectively that lead to goodness and virtue $[10,25]$. Therefore, education as a practical system must be resilient and responsive to turmoil, paradigmatic changes, and transformational changes that need to be started from changes in belief systems.

The contradictory phenomena currently being raised show that the application of management theory and modern educational leadership is not fully able to balance the global and lifestyle challenges occuring in millennial societies. They tend to be more individual and materialistic, so that they are slowly starting to shift the noble values of the nation.

Indonesian, especially students, are also directly involved in the dynamics of the onslaught of technology, such as the existence of smartphones gives students freedom to access information and make social media relationship without being balanced with the strengthening of the moral and cultural values of the nations so that it is possible to eliminate elements of local wisdom. It cannot be denied that this development has made positive contributions to unlimited access to information, thereby it can increase the student knowledge. On the flip side, students still need guidance and assistance in order to reach emotional maturity so that they are able to solve various problems and disharmony that will occur in their lives [29].
Various acts of radicalism and other deviant behavior that involve students such as brawls, a culture of cheating, motorbikes, punk-free life, bullying at school, and promiscuity are a frightening threat to future generations. Corruption, collusion, nepotism, violence, racism, the destruction of nature, criminal acts, drug abuse, law violations, and others continue also to be rampant in Indonesia. For examples, the massive demonstrations by university- students, the community, and even senior high school students intensified in 2019 resulted in anarchist acts and violence, the issue of racism occurred in Papua which resulted in inter-ethnic intolerance, forest fires that occurred on the islands of Sumatra and Kalimantan which getting worse and continuing to expand, and the various corruption cases of officials that are so rife in Indonesia. Today, education observers and activists seem to be jolted by a single awareness and question, "why the development of science, the application of various modern educational management theories, and educational development strategies do not necessarily lead students, to continue to do good and spread virtue in the face of the earth?".

Presidential Regulation No.87 of Year 2017 concerning to character strengthening explains that the character education movement is under the responsibility of the education unit through the harmonization of heart, feeling, thinking, and sports. Schools as formal educational institutions are responsible for strengthening the character of students through education and continuous development through learning interactions and other school activities [31]. Strengthening the function of schools as educational institutions and fostering student character needs to be improved in order to keep up with the rapid development of technology and science so that the achievement of national education goals can be met.

The success of the implementation of character education needs to be more directed at achieving results that are reflected in the behavior shown by students in social interactions and strong personal character. Of course, this is difficult to achieve if the educational environment itself is not yet a role model for students. The principal as the top leader in the school institution must be a role model for the school environment $[21,26]$. Current leadership models still view that the essence of leadership is only limited to a mandate from humans without appreciating that the position it gets is a mandate from humans and God. So, it is not surprising that school members are encouraged to be materialistic and selfish, leaving an altruistic appeal that emphasizes exemplary, humanitarian and selfless values. This leadership crisis is caused by a decline in human values caused by ethical malaise and ethical crisis. Therefore, spiritual leadership management is needed in responding to the challenges of globalization as mentioned above.

The above problems encourage researchers to examine the specific characteristics of integrated Islamic schools in an effort to strengthen student character, with a focus on: (1) resources that build student character values, (2) spiritual leadership programs, (3) spiritual leadership management implementation strategy. The formulation of the problems are: (1) What are the sources of character development for students 
in integrated Islamic elementary schools in Aceh Province? (2) What programs to strengthen student character are carried out by school principals in integrated Islamic elementary schools in Aceh Province? What are the strategies adopted by the principal in an effort to strengthen the character of students in integrated Islamic elementary schools in Aceh Province?

\section{METHODS}

This research is a qualitative descriptive study. Qualitative descriptive research is a data processing method by analysing the factors related to the object of research in depth through the instruments that have been provided.

Data collection was carried out through observation instruments, interviews and documentation studies. This research was conducted in twenty Integrated Islamic Primary Schools in Aceh Province. The sampling technique used was purposive sampling. The research subjects involved in this study were 60 respondents. To obtain valid and reliable analysis results used triangulation analysis techniques.

\section{RESULTS AND DISCUSSION}

\section{A. Sources of Student Character Values in Integrated Islamic Primary School in Aceh Province}

The implementation of character education cannot be separated from the sources of character itself, an interesting things to point out in this study is how the collaboration of character values in integrated Islamic schools is held. Based on the results of the study, it was found that the sources of student character values came from religion, state, education and culture and norms in society. For more details, it will be described in the following Figure 2.

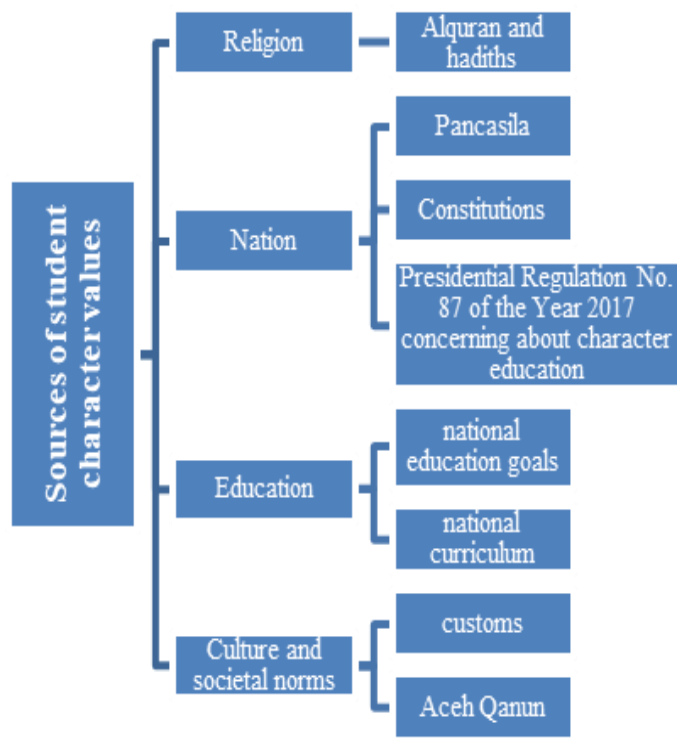

Fig. 2. Sources of student character values of integrated Islamic schools in Aceh Province.
Based on the picture above, it can be discussed that the main source of student character values at the integrated Islamic school in Aceh Province comes from:

1) Religion: Aceh province as one of the provinces with most of its people adhering to Islam, cannot be separated from the influence of Islamic values in the structure of everyday people's lives. They are very attached consciously and unconsciously adopt Islamic character values that come from Alquran and hadiths. Alquran and sunnah become the primary sources for them in behaving [9]. It sourced from the values of Islam listed through the verses in $\mathrm{Al}$ qur'an and the hadiths of the Prophet Muhammad.

2) Nation: The source of character values is derived from precepts and the elaboration of the points of Pancasila as the basis of the state of Indonesia and the national constitution. Aceh as part of the unitary republic of Indonesia also adheres to Pancasila and constitutions as the basis of the state and is used as a reference for developing the character of students as good citizens [30]. In an integrated Islamic school, the national character comes from Pancasila and constitutions is also absorbed as character values that are developed such as love for the country, mutual cooperation, tolerance, fairness, wisdom, and so on. While the character sources contained in presidential regulation no. 87 of 2017 concerning character education include upholding religious values, honesty, discipline, hard work, creative, independent, democratic, curiosity, national spirit, love of the country, love to read and etc.

3) Education: The main dimension of the development of character education in schools that comes from the national education goals, the national curriculum 2013, in accordance with the mandate of law No. 20 of year 2003 concerning the Indonesian national education system. The character programs and values should be one of important component embedded in currect curricula, character education will be achieved with the support of the national education system [25].

4) Culture and societal norms: Each region in Indonesia has a unique character value of local wisdom as well as Aceh Province which is closely related to characters that come from Acehnese customs and qanuns. Qanun is a statutory regulation similar to a regional regulation which regulates the conduct of community life in Aceh Province.

\section{B. Spiritual Leadership Programs in Strengthening Student Character}

Spiritual leadership programs in strengthening student character are related to student character development in schools based on the programs planned by top management. It carried out through integrating to curricular activities, extracurricular activities, and habituation. The spiritual leadership program in strengthening student character is depicted in the following Figure 3. 


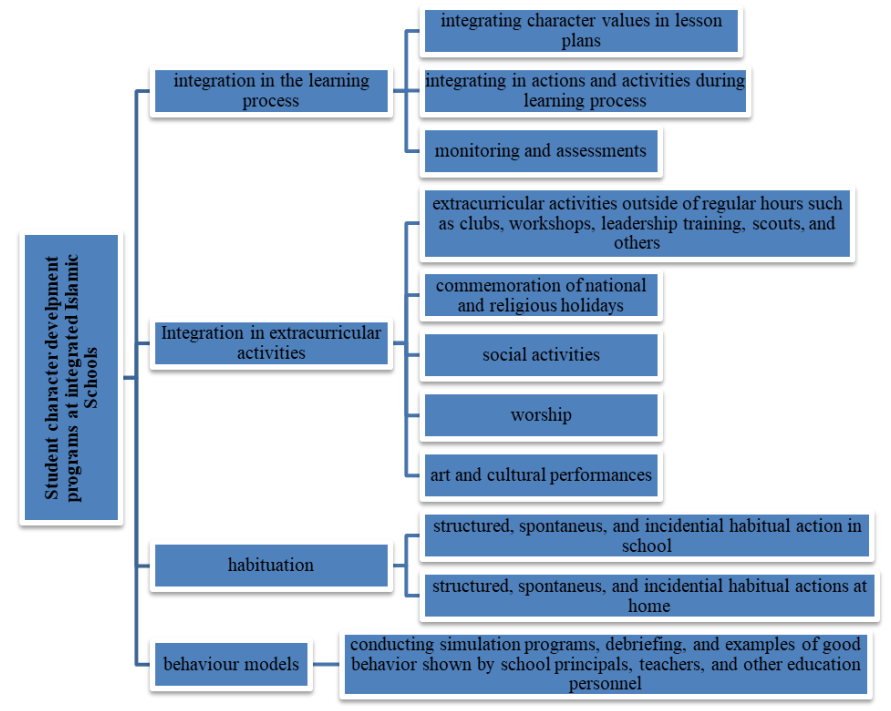

Fig. 3. Students character development programs at integrated Islamic schools in Aceh Province.

In integrated Islamic elementary schools, students' character strengthening programs are integrated in:

1) Curricular activities: In this case, character values are embedded into teacher's lesson plans, throughout the learning and teaching process, monitoring, and assessments. The learning processes not only develop their ethical, experential, and intelectual fundation character but also continuous experience throughtout their life [25].

2) Extracurricular activities: Character values are integrated in extracurricular activities outside of regular hours such as clubs, workshops, leadership training, scouts, and others, commemoration of national and religious holidays, social activities, worship, art and cultural performances.

3) Habituation: In a series of habituation programs at school, the school management made structured habitual actions for students such as disipline, doing congregational prayers, honesty, and etc, while teachers spontaneusly and incidentially remind students repeatedly about good character and reprimand students for doing bad things. The concept of moral and character is easy to introduce to the children [32].

Integrated Islamic elementary schools in Aceh also collaborate with students' parents to control and monitor students to carry out character development on an ongoing basis and assess the success of student character development. The positive social relations and caring community between the school and parents such as parents involvement, bonding family to school provide the greater success on the character development of students [30]. A spritual leader can easily build the relationships and develop great contacts through networking and partnering with the stakeholders [26].

4) Behaviour models: Behaviour models are programs and activities conducted by school through behaviour act simulation, debriefing, and examples of good behavior shown by school principals, teachers, and other education personnel continuously.

The research results above show the suitability of elements in the development of character education as suggested by Battistich that some programs can optimize the students' characters: (1) build caring and supportive relationships in the classroom and throughout the school; (2) model positive behavior; (3) create opportunities for students to be actively and meaningfully involved in the life; (4) teach essential social and emotional skills; (5) involve students in moral discourse; (6) make learning tasks meaningful and relevant to student's life; (7) leave no child behind [27].

\section{Spiritual Leadership Strategies in Strengthening Student Character}

The spiritual leadership strategies carried by the principal in strengthening the character of students are summarized into the Figure 4 below.

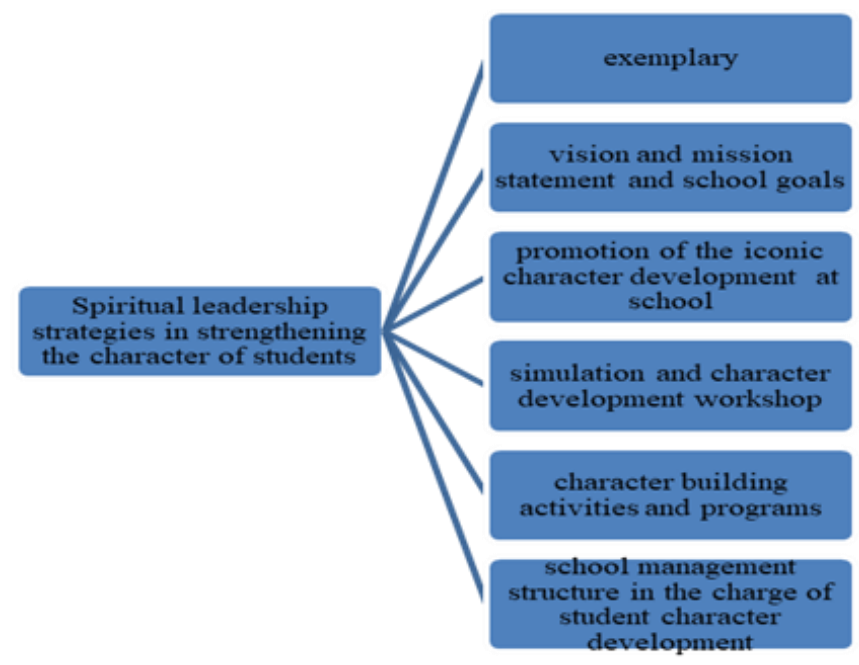

Fig. 4. Spritual leadership strategies in strengthening the student character of Islamic integrated primary school in Aceh Province.

There are some strategies applied by the principals in strenghening the character of students.

1) Exemplary: Examplary is a strategy launced by the principal by making himself a role for students both through actions and words that appear in daily activities. The examplary leadership strategy is the competency and characteristic that leading by showing concern for others and being responsive to others needs, it treats people with the kindness, generosity, and greater good for others [26].

2) Vision, mission statement and school goals: Vision, mission statement, and school goal is an important part that is used as the main foundation in achieving school goals. The existence of vision and mission that is closely related to the character development of students make it easier for spiritual 
leader to determine the right steps in making policies related to student character development.

The essential of spiritual leadership is creating a vision wherein the principals and school members experience a sense of calling so that their lives have purposes and meaning [15]. Developing vision for improving school performance is the main focus of spiritual leader, she/he create a road map for getting to proper place building the greater success of school, he/she uses the vision statement of the school to spark interest in all stakeholders [26]. The spiritual leader also motivates others to pursue organizational vision and mission [33].

3) Promotion of iconic characters of the school: Most integrated Islamic primary schools promote iconic characters carried by each school, this strategy is made to encourage the public interest to the school and become the core of the character's uniqueness developed by the school in addition to other characters. The promotion of character does not just become the leap service but should be action plans for practice [25].

4) Simulation and character building workshop: Simulation strategies and workshops on character development are intended as intial introduction for students and school members to character practices at school, usually through role playing and stimulation.

5) School activities and programs: Integrating character values in all school activities and programs is considered effective in efforts to strengthen student character. Spiritual principal must have program and activities designs to optimize the application of character values in school culture, teaching and learning activities and thers as mentioned in the previous section.

6) School management structures in charge of character development: In some integrated Islamic primary school structures, it was found that schools specifically concerned with the development school culture and character so that the optimization of the achievement of character practice could be obtained. The departmental structures and curriculum also the part of the effort to embrace character education at school [25]. Having the right school management structures can be the fuel that lifts creative ideas to steer, direct, and assist the school in realizing character development goals [26].

\section{CONCLUSIONS AND RECOMMENDATIONS}

\section{A. Conclusion}

The application of Islamic spiritual leadership management in integrated Islamic primary schools is proven having positive influence on strengthening the character of students. Character education is not a quick process to change the bad character to be good, it needs commitment actions and the collaboration of school, parents and other stakeholders to eliminate the bad effect of cultural issues and globalization. Based on the research findings, we conclude some points. First, the sources that build student character values in integrated Islamic primary school include: (1) Religious sources (Al-Quran and hadith), (2) nation (Pancasila, constitutions, and presidential decree No.87 of year 2017 concerning about character education, (3) education (national education objectives and national curriculum), and (4) Culture and societal norms (Aceh customs and qanuns).

Second, the principal's spiritual leadership program is integrated into curricular and extracullicular activities, habituation, and behaviour model. Third, the spiritual leadership strategy is carried out through exemplary, vision, mission and school goals, school distinctiveness icons, Simulation and character building workshop, school activities and programs, and school management structure in charge of school culture and character.

\section{B. Recomendations}

First, we noticed that there are still lack studies examine the Islamic spritual leadership especially in education sector. The further studies about spiritual leadership management from other perspectives are needed to be investigated.

Second, spiritual leadership management is one of the right approach applied in schools, so it is hoped that there will be special trainings for principals to increase their understanding about spiritual leadership manangement.

Third, the principals are expected to continuously and inovatively develop character building programs for all school members. Fourth, all the school members are expected to be role models in instilling good character values in every movement, speech, and action. Fifth, parents and stakeholders should support and participate actively in the success of al activities and character building programs for students both at school and in their interactions with the community.

\section{REFERENCES}

[1] P. Law, Spiritual leadership. Leadership: Perspectives from the frontline. Randburg: KR Publishing, 2016, pp. 443-456.

[2] L.W. Fry, Spiritual Leadership. Global Encyclopedia of Public Administration, Public Policy, and Governance, 2016, pp. 1-6.

[3] M. Benefiel, "The second half of the journey: Spiritual leadership for organizational transformation," The leadership quarterly, vol. 16, pp. 723-747, 2005.

[4] P.H. Scott and S. Tweed, "Implications of Spiritual Leadership on Organizations," Journal of Education \& Social Policy, vol. 3, no. 6, pp. 66-70, 2016.

[5] L.W. Fry and M.P. Cohen, "Spiritual Leadership as a Paradigm for Organizational Transformation and Recovery from Extended Work Hours Cultures," J. f Bus. Ethics, no. 84, pp. 265-278, 2009.

[6] P.V. Nguyen, K.T. Tran, K.H. Dao, and H.P. Dinh, "The Role of Leader's Spiritual Leadership on Organisation Outcomes," Asian Academy of Management Journal, vol. 23, no. 2, pp. 45-68, 2018.

[7] B.S. Cheng, D. Boer, L.F. Chou, M.P. Huang, S. Yoneyama, D. Shim, .. and C.Y. Tsai, "Paternalistic Leadership in Four East Asia Societies: Generalizability and Cultural Differences of the Triad Model," CrossCultural Psychol., vol. XX, no. X, pp. 1-9, 2013. 
[8] I.F. Albuquerque, R.C. Cunha, L.D. Martins, and A.B. Sa, "Primary health care services: workplace spirituality and organizational performance," Journal of Organizational Change Management, vol. 27, no. 1, pp. 59-82, 2014.

[9] C. Frisdiantara and P. Sahertian, "The Spiritual Leadership Dimension In Relation to Other Value-Based Leadership in Organization," International Journal of humanities and social science, vol. 2, no. 15, pp. 284-290, 2012

[10] W. Althof and M.W. Berkowitz, "Moral education and character education : their relationship and roles in citizenship education," Journal of moral education, vol. 35, no. 4, pp. 495-518, 2006.

[11] J. Samul, "Spiritual Leadership: Meaning in the Sustainable Workplace," Sustainability, vol. 12, p. 267, 2020.

[12] E. Egel and L.W. Fry, "Spiritual Leadership as a Model for Islamic Leadership,” Public Integr., vol. 19, no. 1, pp. 77-95, 2017.

[13] L.W. Fry and L.L. Matherly, "Spiritual Leadership as an Integrating Paradigm for Positive Leadership Development Spiritual Leadership as an Integrating Paradigm for Positive Leadership Development," Washington, DC: International Gallup Leadership Summit, vol. 76549 , no. $254,2006$.

[14] L.W. Fry and J.W. Slocum, "Maximizing the Triple Bottom Line through Spiritual Leadership," Organ. Dyn., vol. 37, no. May 2018, pp. 86-96, 2008.

[15] L.W. Fry, "Toward a theory of spiritual leadership," The leadership quarterly, vol. 14, no. September, pp. 693-727, 2003.

[16] L.W. Fry, S.T. Hannah, M. Noel, and F.O. Walumbwa, "Author ' s personal copy Impact of spiritual leadership on unit performance," 2011.

[17] L.W. Fry, L. Sedgmore, and Y. Altman, Maximizing the triple bottom line \& spiritual leadership: The Cel Story. Chicago Illinois: Academy of Management Meeting, 2009.

[18] L.W. Fry and J.L. Whittington, "Spiritual Leadership as a Paradigm for Organization Transformation and Development," National Academy of Management Meeting. Honolulu, Hawaii, vol. 75062, no. 9720, 1901.

[19] L.W. Fry, "Spiritual Leadership as a Model for Student InnerDevelopment," Journal of leadership studies, vol. 3, no. 3, pp. 7983, 2009.

[20] L.W. Fry, L.L. Matherly, and J. Ouimet, "The Spiritual Leadership Balanced Scorecard Business Model: the case of the Cordon Bleu-
Tomasso Corporation," Journal of Management, Spirituality and Religion, vol. 7, no. 4, pp. 283-314.

[21] P.J. Sweeney and L.W. Fry, "Character Development through Spiritual Leadership," Consulting Psychology Journal: Practice and Research, vol. 64, no. 2, pp. 89-107, 2012

[22] L.W. Fry and J.W. Slocum, "Maximizing the Triple Bottom Line Through Spiritual Leadership," Organizational dynamics, vol. 37, no. 1, p. 86,2008

[23] C.Y. Chen and C.F. Yang, "The Impact of Spiritual Leadership on Organizational Citizenship Behavior: A Multi-Sample Analysis,' Journal of business ethics, vol. 105, no. 1, pp. 107-114, 2012.

[24] K. Rezach, Spiritual Leadership as a Model of Effective Leadership in Independent Schools. Seton Hall University, 2002.

[25] A. Agboola and K.C. Tsai, "Bring Character Education into Classroom," European journal of educational research, vol. 3, no. 2, pp. 163-170, 2012.

[26] S. Thompson, "Hidden Strength: Encouraging Spiritual Leadership Attributes Among School Leaders," Kentucky Journal of Excellence in College Teaching and Learning, vol. 10, no. January, p. 9, 2013.

[27] M. Gagne, "A model of knowledge-sharing motivation," Hum. Resour. Manage., vol. 48, no. 4, pp. 571-589, 2009.

[28] M. Karadağ, F.A. Aksal, and Z.A. Gazi, "Effect Size of Spiritual Leadership : In the Process of School Culture and Academic Success,' SAGE Open, vol. 10, no. 1, pp. 1-14, 2020.

[29] V. Battistich, Character Education , Prevention , and Positive Youth Development. Washington, DC: Character Education Partnership, 2001, pp. $1-10$.

[30] C. Jones and S. Thoma, Character Education in UK Schools Birmingham: School of Education, University of Birmingham, 2015.

[31] L. Nucci and D. Narvaez, Handbook of Moral. Routledge, 2014.

[32] H. Buchs and L.A. Helbling, "Job opportunities and school - to - work transitions in occupational labour markets . Are occupational change and unskilled employment after vocational education interrelated ?," Empir. Res. Vocat. Educ. Train., vol. 8, no. 1, pp. 1-18, 2016.

[33] J. Oh and J. Wang, "Spiritual leadership : current status and Agenda for future research and practice,” J. Manag. Spiritual. Relig., vol. 00, no. 00, pp. 1-26, 2020 . 